\title{
Resources Factors in the Implementation of Sinabung Eruption Disaster Mitigation in Gung Pinto Village, Karo Regency
}

\author{
Rudi Kristian P. M $^{1, *}$, Deddy Hutapea ${ }^{2}$ \\ ${ }^{1,2}$ Public Administration Studies Program \\ ${ }^{1,2}$ Faculty of Social and Political Sciences, Universitas Sumatera Utara \\ Email: rudimanurung@usu.ac.id
}

\begin{abstract}
Disaster mitigation consists of structural mitigation and non-structural mitigation. Structural mitigation is a form of mitigation that is physically related. In the implementation of non-structural mitigation, the role of citizens is important and necessary so that the implementation of mitigation can be in accordance with the plan. Disaster mitigation programs can be implemented through increased education about disasters, socialization, simulations, and several other activities aimed at increasing community capacity. One form of mitigation carried out by the Karo Regency BPBD is through the creation of the Disaster Resilient Village (Destana) program. In its implementation, the mitigation carried out is still experiencing problems, one of which is limited resources. This study aims to describe the function of resources in the implementation of disaster mitigation in the village of Gung Pinto. The research method used in this study is a qualitative research method. Primary data obtained through observation and interviews were then analyzed using the Neuman model. Research problems related to the implementation of mitigation will be described using the resource concept according to George Edward. The research results are described as follows; Human resources owned by BPBD Kab. Karo in quantity is sufficient, while in quality it is necessary to provide training related to disasters, while the facility resources in supporting the Destana program are not sufficient, as well as the utilization of the authority possessed by BPBD has not been optimal because the work of the organization focuses on the work that has been done. planned.
\end{abstract}

Keywords: Disaster, Eruption, Mitigation, Resources

\section{INTRODUCTION}

Indonesia, a country which has huge numbers of disasters, needs to start education of disaster among the community, especially in disaster-prone areas. Based on Law Number 24 Year 200724 [1] concerning Disaster Management, a disaster is an event or series of events that threatens and disrupts people's lives and livelihoods caused, both by natural factors and/or non-natural factors as well as human factors, resulting in human casualties, environmental damage, property losses, and psychological impact. Meanwhile, according to John Hopkins and The International Federation of Red Cross and Red Crescent Societies [2], disasters can be divided into three groups consisting disasters from forces in nature, disasters with humans as a factor, and disasters directly caused by people. The two references related to disasters above show that the red line from the definition of disaster is an event that threatens the lives of living things on earth as a result of natural, nonnatural activities and can even be caused by human activities. Then, based on the risks, BNPB stated that there are four classifications of disaster risk, namely: geological disasters, hydrometeorological disasters, biological disasters, and disasters caused by technological failures. The definition states that disaster risk can be because of natural, non-natural, and human factors. So serious disaster management is needed.

In the 'disaster management 'context, 'preparedness' and 'response' are often considered 'mitigation' [3]. Mitigation has a significant role in helping residents avoid disasters, or during disasters, residents can protect themselves from disasters.

Mitigation can be defined as an attempt to decrease and prevent wealth and life loss risks, through approaches of structural and non-structural [4]. Mitigation of structural is an attempt to decrease disaster risks through physical establishment and 
technical-engineering of disaster-resistant buildings, on the other side, non-structural is decrease attempt of the disaster non-physical risks of disaster such as policy, the empowerment of community, institutional reinforcement, and awareness [5]. To reduce risks of disaster, mitigation of non-structural will be more sustainable because it gives long term safety. So that ability to deal with hazards and disaster risks is inherent in the community.

In 2017 the Sinabung Volcano Disaster Socialization was carried out in Gung Pinto Village. The socialization carried out is related to the mitigation of volcanic eruption disasters. Gung Pinto Village is located on the southwest slope of Mount Sinabung with a distance of $4.5 \mathrm{~km}$ from the summit. This village is located in the Zone of Disaster Prone Areas (KRB) III. Socialization related to disaster mitigation is carried out so that the community is increasingly aware of their responsibilities in disaster management.

Volcanoes have a dangerous side with the threat of eruption that needs to be monitored continuously. The term "mitigation" means "the process of preventing disasters or reducing related hazards". Volcanic eruption disaster mitigation is "the process of preventing volcanic eruptions or decreasing volcanic eruptions impact" to reduce loss of life and property, environmental damage, and disruption of the community's economy.

The phenomenon of Mount Sinabung which has continued to erupt since 2013 and has not stopped until October 2021. So that the people of Gung Pinto village who are in the Disaster-Prone Area III (radius $6 \mathrm{~km}$ from Mount Sinabung) must be given an understanding of the potential for eruption disasters and strengthening capacity in dealing with the eruption of Mount Sinabung when it erupts.

One way to reduce disaster risk is through mitigation efforts, namely by mapping the vulnerability level, vulnerability, also risks of disaster in form of cold lava floods, forest, and land fires [6]. Mapping aims to determine the distribution of disaster locations and the area of disaster risk.

In disaster management, the cycle consists of three stages. Stages before disaster (pre-disaster), during disaster, and after disaster [7]. Furthermore, Khan emphasized that disaster mitigation (before the disaster) should be implemented to lower losses (minimize losses). Activities which are taken prior to a disaster to lower losses of human and property because of a potential danger. For example, campaigns of awareness, strengthening existing structures which are weak, prepare management plans of disaster in the level of community and also at the household, etc. such measures of risk reduction are for activities of mitigation and preparedness.

Edward argues that program success is closely related to communication, resources, bureaucratic structure, and disposition [8]. These categories are interrelated in the implementation of a program. So that the successful implementation of the program (disaster mitigation) will experience problems if there are no adequate resources such as what happened in the village of Gung Pinto where in the implementation of mitigation, existing resources human(residents) are still experiencing problems, considering that residents who tend to have lower secondary education. So that the weakness of human resources will have an impact on the communication category carried out by the government and the Center for Volcanology and Geological Hazard Mitigation (PVMBG) in form of unsuccessful socialization. The intensity of communication is important because according to Edward, the communication delivered must be clear, consistent and reach the community in accordance with the plan for the formation and objectives of the program [8].

Clear and consistent communication is something that the government must maintain in socializing disaster mitigation. This is closely related to what Dussuet and Ledoux conveyed; "for a long time, policy implementation studies have demonstrated that streetlevel organizations and frontline workers are central to the shaping of welfare policies" [9]. It was stated that policymakers are not policy implementers. The implementers of the policy are street-level organizations. So that the communication ability of street-level organizations in conveying mitigation information needs to be considered. Consistency is an important point to avoid information bias or misrepresentation. When talking about the capabilities of the street-level organization, we are talking about human resource capabilities, financial support, and facility resources.

Implementation of mitigation becomes important after a decision is made. However, the main goal of decision-making is the achievement of the planned goals in decision-making. To describe how the resources in the implementation of Sinabung volcanic disaster mitigation through the Tangguh disaster village program, research needs to be carried out. It is hoped that this research can provide description of resources in disaster mitigation implementation.

\section{RESOURCES IN PUBLIC POLICY}

Public policy is a science that has a wedge between administration public and political science. Harold Laswell and Abraham Kaplan [10] define public policy as "a projected program which has some purposes, values, and certain practices". From this definition, George C. Edwards III and Ira Sharkansky [11] provide a definition of public policy "a government program to achieve purposes". From these two definitions, it can be understood that public policy is a government program for achieving purposes. It can be concluded that policies are tools (tools) in achieving goals.

Policy as a tool cannot be separated from the process. The process will be related to the hierarchy. 
Bromley [12] provides an explanation of the policy process as a hierarchy as follows:

1. There will be decisions regarding the boundary between market and non-market processes. This determines the locus of control for many economic decisions.

2. There will be decisions taken with respect to the allocation of net benefits from various economic endeavors. Here one has a tax policy that will determine the distribution of income among members of the society.

3. The third policy level decision concerns the conditions under which change is called for in the prior two types of collective decisions

If referring to the hierarchy of policy processes described by Bromley, where there are Policy Level, Organizational Level, and Operational Level, then independent relocation settlements due to the eruption of the Sinabung Volcano are at The Policy Level is at the Central Government, the Organizational Level is at the National Disaster Management Agency, and the Operational Level is at the Karo Regional Disaster Management Agency (Karo District Government).

However, public policy won't produce anything if it is only a draft, so that policy implementation is absolutely needed, so that policymakers can see whether the policies made can achieve the goals, are exactly as desired, and what are the shortcomings of the policy. The implementation of the policy becomes a benchmark for whether the policy is good or bad, successful or unsuccessful.

Edwards stated that the implementation process as:

"...the state of policymaking between the establishment of a policy (such as the passage of a legislative act, the issuing of an executive order, the handling down of a judicial decision, or the promulgation of a regulatory rule) and the consequences of the policy for the people whom it effects." [8]

In the developed model, Edwards suggests four critical factors that influence policy implementation successfulness. The four variables are; Communication variable, Resource variable, Implementing Disposition or Attitude variable, and Bureaucratic Structure variable, all of which are interconnected and influence each other to determine implementation successfulness.

In this study, main focus is resources so that discussion is limited to the resource variable. Resources, Edwards [8] explains that the things needed for effective implementation are: Important resources include staff of the proper size and with the necessary expertise; relevant and adequate information on how to implement policies and on the compliance of others involved in implementation; the authority to ensure that policies are carried out as they are intended; and facilities (including buildings, equipment, land, and supplies) in which or with which to provide services.
Implementation orders which are well known and consistent, also how accurate instructions are sent. However, if the implementing organization that implements the policy lacks resources, then there will be ineffective implementation. The resources referred to by Edwards [8], as mentioned above include staff, information, authority, and facilities. Resources in the form of staff are not limited to human figures, but also humans who have the skills needed in implementing the policy. Often new obstacles arise, the quantity of staff that is owned is sufficient, but in terms of skills, the staff is not sufficient. While the facilities in question can be in the form of facilities, either in the form of physical facilities or training/education which aims to get staff who have skills/quality.

In line with Edwards, Dussuet and Ledoux [9] assert; frontline workers find spaces in which they can take decisions and identify methods to solve their problems... resources in this case field staff, in the concept of Dussuet and Ledoux known as frontline workers, are people who have direct contact with program or service recipients. So that frontline workers must have the ability to identify problems and make decisions while in the field/program implementation. Therefore, human resources who make contact with program recipients/program targets must be trained and experienced personnel.

\section{MITIGATION}

In disaster management, various efforts are needed to overcome various disaster events in Indonesia, both in the form of infrastructure development and various mitigation efforts (non-infrastructure) [13]. In disaster management, the strategy must be adapted to the disaster to be overcome. Sadisun states that one of the strategies for disaster management is to carry out regular and sustainable mitigation [13].

Mitigation of disaster is consisted of structural and also non-structural. Mitigation of Structural can be seen as form of mitigation that is physically related. In the implementation of non-structural mitigation, the role of citizens is important and necessary so that the implementation of mitigation can be in accordance with the plan [14]. Mitigation carried out can be in the form of socializing the impact of disasters, training on disaster management to creating and using village information media as a means of disseminating information.

So that the mitigation carried out is closely related to the capacity of the residents. Mitigation will be successful if there is an increase in the capacity of the residents and a change in attitude in dealing with regular volcanic eruptions.

Volcanic eruption disaster mitigation activities include (1) volcanic investigation; to determine the character and nature of the eruption (2) Mapping of disaster-prone areas; such as determining areas that are vulnerable for residents to the threat of hot cloud 
eruptions, lava flows, lava flows, incandescent stones, and ash rain, in the form of maps. (3) Monitoring or monitoring of volcanoes; monitoring activity volcanic with various methods (seismicity, deformation, geophysical measurement of volcanic gas, remote sensing, hydrology, geology and geochemistry), to determine precisely the movement of magma and gas contained therein in the form of surface and subsurface manifestations, (3) Guidance , Information and Recommendations; data and information are packaged in the form of the level of activity volcanic every change in the level of activity volcanic conveyed to the public through the provincial government, district/city governments around the volcano, generating anticipation for the views and reactions of the people who were given "information", (4) Communication and Reporting; interactive communication to facilitate the implementation of disaster management when necessary, reports from each volcano observation post are periodically submitted to the provincial government, district/city government in accordance with the limits of their authority. This mitigation activity is carried out before the disaster occurs but in the case of the eruption of Mount Sinabung, mitigation is carried out after the eruption occurs, this is what makes that in disaster management, the stages run in a circular or cyclical form, so that disaster management does not stop at the end of the stages.

\section{RESEARCH METHODS}

This research uses qualitative approach with descriptive explanation. Data collective done with indepth interview, field observation, and also document. Determination of informant uses purposive sampling technique, and the informant consists of villagers, staff of BPBD, Destana facilitator, and village government. Data and information collected will be through the process of triangulation. Technique and source to support the validation level.

\section{RESOURCES FACTORS IN THE IMPLEMENTATION OF DISASTER MITIGATION THROUGH THE DISASTER RESILIENT VILLAGE PROGRAM (DESTANA)}

The Karo Regional Disaster Management Agency performs disaster management tasks in accordance with the existing disaster management system [1]. The Disaster management system is in accordance with the stages outlined by Khan [7]. Disaster management is divided into three stages, namely; (1) before the disaster (pre-disaster), (2) during a disaster, and (3) Furthermore, Khan emphasized that disaster mitigation (before the disaster) should be implemented to lower losses. Activities which are taken prior to a disaster to lower losses of human and property because of a potential danger. For example, campaigns of awareness, strengthening existing structures which are weak, prepare management plans of disaster in the level of community and also at the household, etc. such measures of risk reduction are for activities of mitigation and preparedness.

In Law Number 24 Year 2007, three affairs in the disaster management stage [7] were adapted into; (1) before the disaster; into the Prevention and Preparedness Sector, (2) during a disaster into the Emergency and Logistics Sector, (3) after a disaster into the Rehabilitation and Reconstruction Sector [1].

In order to increase community roles and public awareness in disaster management, the government facilitates by developing a Community-Based Disaster Risk Reduction program to place the community in an important role in disaster risk management to build resilience to disasters. In this activity, process of disaster risk supervision involves the people actively in assessing, analyzing, managing, monitoring, and evaluating disaster risks to lower vulnerability and higher their abilities. In general, it is carried out through the smallest government unit that can target directly the community, namely in the village or sub-district area.

One of the strategies used to achieve this is through the Disaster-Resilient Village and Sub-District Development Program (Destana/Keltana) which aims to provide guidance for the government and/or local governments, especially at the district level, in developing Disaster-Resilient Villages as an effort to implement disaster reduction. community-based disaster risk and do integration as a part of the District/City Medium-Term Establishment Plan.

A Disaster Resilient Village is a village or urban village which is capable to do adaptation and deal with possibility of disasters. That village or urban village also has to do fast restoration from some impacts of disasters. Then a village could be called disaster toughness when that village has capability to recognize the threats in its territory and able to organize itself with its own resources to decrease vulnerability, also increase capacity to reduce risks of disaster. To become this kind of village, process is absolutely needed. Therefore, village which has people who can do anticipation of threats possibility should be developed by government. It is expected that villagers have ability to study, analyze, handle, supervise, do evaluation, and decrease risks of disaster in their territory by using their own local resources. This capability can be realized in development planning of prevention efforts, awareness, disaster risks decrease, and building of capacity to do recovery after emergency situation.

Karo Regency Government, in this case, the Karo Regency BPBD also wishes to reduce disaster risk in its area, especially in disaster-prone areas. Currently, Karo Regency is still facing the eruption of Mount Sinabung, so it is very important to prepare villages in the Mount 
Sinabung area to face the eruption of Mount Sinabung which can occur at any time. One of the efforts made is to carry out the establishment and development of disaster-resilient villages.

BPBD Karo Regency as the leading sector in implementing the development of Disaster Resilient Villages has an important role to achieve the components possessed by Disaster Resilient Village as follows: Legislation: preparation of Village Regulations that regulate risk reduction and disaster management at the village level. The Karo Regional Disaster Management Agency (BPBD) has established and developed a Disaster Resilient Village (Destana) in order to create a community that is prepared and resilient to disasters. With the establishment of the Destana, community-based disaster management efforts will be developed and coordinated.

The establishment of the village began to be formed in 2019. Many people in the village are not ready to face the disaster, eruption Sinabung 2013 so when a disaster occurs, people are confused about what to do. The establishment of the Destana is very important to do anticipation of disaster in terms of decreasing disasters risks, including reducing the loss of life. Likewise, the impact on the economy, infrastructure, and psychology/social. Disaster responsibility is a trident (government, community, and business), which means shared responsibility.

The villages/sub-districts that are the target of Disaster Resilient Village/Urban Development have certain factors that target the implementation of this development, namely in those areas that have high disaster-prone potentials such as floods, landslides, volcanic activity, forest fires, hurricanes, and earthquakes. Based on the disaster risk study, what is currently urgent is the community in the Mount Sinabung area. And the determination of the Disaster Resilient Village/kelurahan is of course based on recommendations from each sub-district itself and the village apparatus can be invited to work well together.

So far, the Karo Regency BPBD is still focused on handling refugees from the Mount Sinabung eruption who are in refugee posts and temporary shelters and the implementation of refugee relocation in order to disaster-resilient village establishment can be realized in 2019. Whereas other areas in North Sumatra province have implemented the formation of disaster-resilient villages.

\subsection{Resources}

Resources are the main factor in implementing and realizing the course of a policy. Without the availability of resources, it is unlikely that a policy can be implemented optimally. Therefore, resources are important to pay attention to. Although there is clear and consistent communication in the policy contents, but if lack of resources from implementers in doing the policy is there, effective implementation will not be reached. Those resources will be in the formed of human resources, financial resources, and facilities used.

\subsubsection{Human Resources (Staff)}

Staff is the main resource in implementing a policy or program. The lack of implementing staff will certainly hinder the policy course so that policy implementation won't be maximally done. A large number of staff also does not automatically encourage successful implementation. This is due to the lack of skills and motivation possessed by government officials and staff, but on the other hand, a shortage of staff will also create complicated problems regarding effective policy implementation.

The human resources at BPBD Karo are 55 employees with different educational qualifications, consisting of 24 civil servants and 31 honorary employees; consisting of 15 employees computer operators and 16 rapid reaction units (URC). As for the level of education of employees with ASN status owned by BPBD Karo as many as 24 people. The Prevention and Preparedness Division itself has four staff consisting of the Head of Division, two Section Heads, and one staff and assisted by two freelance daily employees (computer operators). In terms of numbers, employees in the field of prevention and preparedness are inadequate in terms of numbers while the main tasks and functions that must be carried out are quite a lot. The number of employees in this field also does not have an educational background in the field of disaster and not all employees attend training in the field of disaster.

Resources staff in BPBD Kab. Karo, especially in the field of prevention and preparedness, on average does not have an educational background in the field of disaster. Officers in the field of prevention and preparedness study regulations related to disasters, consult with other regions or make comparative studies to regions that have implemented the establishment of disaster-resilient villages. This shortage of BPBDs was helped by the placement of village facilitators by the BPBD of North Sumatra Province in Karo Regency. So there is still a need for Village Facilitators from the Province who are experts in implementing Disaster Resilient Villages.

The facilitators came from the BPBD of North Sumatra province who were stationed at BPBD Karo. A village facilitator from the Provincial BPBD directly goes to the village to coordinate with the village community for the Establishment and Implementation of a Disaster Resilient Village (Destana). In addition, there is the Koramil Commander who also gives directions to the community, directions regarding what to do when a disaster strikes. The TNI has been 
involved since the eruption of Mount Sinabung occurred in 2013. At the beginning of the eruption of Mount Sinabung, the Commander for Emergency Response and Operations was Lieutenant Colonel Meyer Putoh who is an element of the TNI, Dandim 0205 Karo

Village facilitator facilitated by the Regional Disaster Management Agency (BPBD) Province of North Sumatra but still lacks in the numbers given. In this case, we can see that the Regional Disaster Management Agency (BPBD) of Karo Regency is only limited to providing suggestions to the province regarding the shortages needed. The BPBD of North Sumatra Province also facilitates village communities that will implement the Disaster Resilient Village Program by bringing in Village Facilitators as experts in the implementation of Disaster Resilient Villages who have been given special training for the implementation of Disaster Resilient Villages.

Human resources in the Establishment of Disaster Resilient Villages Provincial BPBDs provide facilities in the form of facilitators who are experts in the implementation of Disaster Resilient Villages. Officers in the field of prevention and preparedness try to study regulations related to the formation of disaster-resilient villages, coordinate with other regions and conduct comparative studies. In terms of numbers, employees in the field of prevention and preparedness are not adequate, but in carrying out their work, the employees have mastered policies so that the implementation of the formation of disaster-resilient villages can run well even though the implementation time is longer. This is in accordance with Edward's statement which states that one variable which can provide successfulness of policy implementation is human resources [15].

Disposition can be seen as characteristics owned by policy implementers like commitment, honesty, and nature of democratic. If policy implementation is to be effective, then the implementers must not only have capability to do implementation, where policy quality is impacted by features of implementers. Policy successfulness can be known from disposition (implementer agents features). If the implementers are good because accepting a policy, in this case, means there is support, the implementers will be concentrating on the policy more. On the other hand, if there are perspective and behavior differences between implementers and policy makers, the process of policy implementation will encounter difficulties.

The implementers who have different perspectives tend to use their own decisions that are different from the regulations that should be from the policies implemented so that the objectives of the policy are not achieved. According to Edward, there are two things that need to be considered in looking at the disposition of policy implementers, namely the appointment of employees and the incentives provided. The choice of personnel related to the policy implementation, has to be people who will dedicate to the determined policies, especially to the community interests.

The employee selection in field of prevention and preparedness is determined by the Karo Regent through the Karo Regency Regional Personnel Agency so that the employees assigned are not necessarily in accordance with the needs of the Karo Regency BPBD. The right of appointment and placement of employees is determined by the Regional Head based on input from various parties. Until now, employees in the field of prevention and preparedness do not have an educational background related to disasters.

Related to this, the researcher also asked informants about the availability of employees at the Karo Regency Regional Disaster Management Agency (BPBD), along with their responses regarding the availability of employees. The Regional Disaster Management Agency (BPBD) of Karo Regency still has shortcomings related to employee backgrounds that are not in accordance with the field in the office and also an inadequate number of workers. However, there are several employees who have attended disaster-related training, such as the Head of Prevention, Head of Prevention, and Head of Preparedness.

This lack of human resources is covered by the employees learning on their own regarding the implementation of the policy for the establishment of a disaster-resilient village. The employees studied the BNPB Perka related to the establishment of a disasterresilient village and conducted consultations and coordination with BNPB, North Sumatra Province BPBD, and Sleman BPBD. BPBD conducts consultation activities in the 2018 fiscal year. The appointment of employees who are not in accordance with their educational background will certainly hinder the implementation of policy implementation. This can make the performance at the Karo Regency Regional Disaster Management Agency (BPBD) not run effectively and decision making is not on target. However, this deficiency is covered by the dedication of employees as policy implementers who will dedicate to the determined policies, especially to the community interests so that the implementation of the establishment of a Disaster Resilient Village can run well.

This is in accordance with Edward's theory which states that: If policy implementation is to be effective and efficient, the implementers will exactly know their functions and have the ability to do policy implementation [15]. The will to implement the policy is also required. Therefore, the appointment and choice of personnel related to the policy implementation, has to be people who will dedicate to the determined policies, especially to the community interests, it is hoped that in the future, the recruitment of employees for the Karo Regency Regional Disaster Management Agency (BPBD) is carried out by looking at Back to the background possessed by prospective employees so that 
they can be placed in accordance with the fields mastered.

To support policy implementers to work optimally, it is supported by the provision of incentives. Incentive is one of problem solver techniques which can be alternative related to implementer behaviors. It is basic that people are moved by their own interests, so incentive manipulation which is done by policy makers may affect policy implementers actions. To increase some profit or cost may be a factor for getting the best results from implementers. This is for private or organization interests as well. The acceptance or rejection from implementers will affect successfulness from implementation of public policy. This can be seen from role of each employee in the implementation of the DESTANA Program at the Regional Disaster Management Agency.

The provision of these incentives certainly makes the role of employees in carrying out the DESTANA program more leverage, so that the establishment of DESTANA in 2019 was successfully implemented and the community enthusiastically welcomed the implementation of Destana in their village. Changing the attitude of policy implementers in the government bureaucracy is a difficult task and does not guarantee the process of implementation won't face any problems. One of suggested techniques for dealing with the problem of the propensity for implementers is to manipulate incentives. Providing incentives can affect employee performance in increasing employee motivation. From the way of increasing profits or costs, can be a factor for implementers to do good orders implementation.

The provision of incentives to employees already exists through additional employee income. However, in the implementation of DESTANA there are no incentives given to employees at all. It is hoped that in the future incentives will be provided to employees who run the DESTANA program so that employees will be motivated in providing excellent service to the community, especially the implementation of the Disaster Resilient Village (DESTANA) program in accordance with Edward's concern in Agustino [16] suggested to manipulate incentives to overcome policy implementers behavior. Basically, own interests are moving the people, so policy implementers actions are affected from the incentives manipulation done by policymakers. By adding benefits or costs may be a point to make policymakers executing orders well. This effort is done to meet the interests of personal or organizational.

\subsubsection{Financial Resources}

According to Indiahono [17] resource refers to every policy that must get supports from the resources, human resources and financial resources as well. Financial resources are sufficiency of investment capital for a program or policy. Financial resources give guarantee to program or policy continuity. If there is no enough support of financial, program couldn't be run smoothly and quickly, in order to reach the purposes.

Following up on the Regional Medium Term Development Plan (RPJM) based on vision, mission, also program of elected Regional Head for the next 5 years (2016 - 2021), the Karo Regency Regional Disaster Management Agency is required to prepare a strategic plan which will then be used as a strategic tactical planning document. which describes the handling of disaster management in Karo Regency as well as an indication of the list of programs and activities that will be carried out to carry out disaster management in a planned and directed manner through both APBD and APBN funding sources, by prioritizing standard disaster management procedures in accordance with priority needs for disaster management and management based on statutory regulations. invitation.

Based on the Strategic Plan (Renstra) of the Karo Regency Regional Disaster Management Agency for 2016-2021 and in Government Regulation Number 22 of 2008 concerning Funding and Management of Disaster Assistance Funds as referred to in article 6, in general, management of disaster countermeasures are before disaster, during response of emergency, and/or after disaster. Priority for disaster management needs stage of before disaster from BPBD Karo Regency, that is the establishment of a Disaster Resilient Village. For the 2016-2021 Strategic Plan, the target is the establishment and development of 5 Disaster Resilient Villages. In 2019, the establishment and development of 2 disaster-resilient villages have been carried out, namely Naman village and Sukatendel village.

In 2020 it was carried out in 8 villages, namely Gung Pinto Village, Kutarakyat Village, Naman Teran District, Tigapancur and Pintu Besi Villages, Simpang Empat District, Perbaji Village and Kutambaru Village, Tiganderket District, and Payung Village and Selandi Village, Payung District. The budget used for the establishment and development of the disaster Tangguh village in the field of prevention and preparedness for the 2020 fiscal year is Rp. 658,000,000,-. The village facilitator's salary budget, is accommodated at the BPBD of North Sumatra Province with a salary of \pm Rp. 5.000.000,- per month.

The establishment and development of the Disaster Resilient Village initially used the Karo Regency APBD which was accommodated at the Karo Regency BPBD. The Disaster Resilient Village follow-up program (DESTANA) no longer uses budget funds from the Karo Regency BPBD, but uses the Village Fund. The Village Facilitator also stated that the budget for the establishment of a disaster-resilient village was from BPBD Karo but the salary for village facilitators was from the BPBD budget for North Sumatra Province. The Village Head and the Chair of the Destana Forum 
agreed with this. Based on the information obtained from the informants above and the documents collected, it can be concluded that the budget used in the establishment of the Destana was sourced from BPBD Kab. Karo. The budget used to implement the policy for the establishment of a disaster-resilient village is sufficient from formation to development. BPBD of Karo Regency Uses the budget by prioritizing standard procedures for disaster management in accordance with the priority needs of disaster management and management based on statutory regulations.

Based on an interview with the Head of the Destana that the establishment of the Destana initially used funds from the District BPBD. Karo but for the next in the development of the District BPBD Destana. Karo also asked the Village Head to accommodate the village fund budget for the continuation of Destana activities in the village. To implement a policy must be supported by adequate resources. The Karo Regency BPBD has budgeted an adequate budget for the establishment of a disaster-resilient village in the Kab. Karo. The budget is used for outreach activities, training, procurement of signs and information boards, procurement of banners, procurement of HT, and Toa. Adequate budgeting is in accordance with Edward III's theory, states that limited available budget makes limitation of quality services for community as well.

\subsubsection{Facility Resources}

Staff which is good enough, have capability, and also competent is may be had by policy implementers, but without supporting facilities and infrastructure, policy implementation won't work well. Based on observations and research data, the facilities at BPBD Karo Regency are quite good. This is because each employee room has air ventilation large enough to circulate cool air from outside because the Kabanjahe area is already cool because it is in a highland area, this is the reason the employee room at BPBD Karo Regency is quite comfortable even though it does not use Air Conditioner (AC).

From above information, we can conclude, the regional Agency of Management of Disaster is also equipped with adequate tools to support the performance of Disaster Management such as vehicles that can evacuate the community during disaster condition. To implement Disaster Resilient Village (DESTANA), the Karo Regency BPBD prevention and preparedness sector as the main implementer in this policy uses the above facilities such as sound systems, projector, official vehicles, BNPB donation folding tables, laptops, and other facilities. In addition to using the facilities owned by the Karo Regency BPBD, in carrying out the establishment of a disaster-resilient village, the BPBD accommodates the budget for providing facilities for the fostered villages such as HT, Toa, Information Boards, kentongan (traditional communication instrument made from bamboo or wood), Flipchart Boards, and Plank Disaster-prone signs.

The facilities provided by the Karo Regional Disaster Management Agency (BPBD) to support implementation of Disaster Resilient Villages for community are generally not adequate. In the implementation of the establishment of the Disaster Tangguh village, the Karo Regency BPBD is supported by adequate facilities so that the implementation of the policy can run well. However, the facilities provided directly to the community are still inadequate, this is an obstacle that must be addressed in the future in accordance with Edward's opinion which states that instrumentation of resource is used to do policy implementation operation of structure, ground, and tool, all will be implemented to make easier in giving services of policy implementation.

\section{CONCLUSION}

In terms of quantity, the human resources are owned by Karo BPBD is sufficient. The number of employees is about 56 people with various educational backgrounds. However, the average BPBD employee does not have an educational background in the field of disaster, especially employees in the Prevention and Preparedness Sector, but the BPBD employees of Kab. Karo Learned on his own over time by studying disaster-related regulations, consulting with other regions, or comparative studies to areas that have already implemented the establishment of disasterresilient villages. The budget disbursed to BPBD in the context of disaster management is also sufficient and even abundant, also equipped with adequate tools to support the performance of Disaster Management such as vehicles that can evacuate community during disaster situation. Karo Regency BPBD prevention and preparedness sector as the main implementer in this policy uses facilities such as sound systems, projector, official vehicles, folding tables for BNPB donations, laptops, and other facilities. In addition to using the facilities owned by the Karo Regency BPBD, in implementing the establishment of a disaster-resilient village, the BPBD accommodates the budget for providing facilities for the fostered villages such as HT, Toa, Information Boards, kentongan (traditional communication instrument made from bamboo or wood), Flipchart Boards, and Disaster-Prone Signs. However, not all villages have received adequate facilities, one of which is Gung Pinto village. In the future, this will be corrected by the Karo Regency BPBD in supporting adequate facilities in the village so policy implementation will be smoothly done.

In addition, Human Resources In general, the employees are determined by the Karo Regent through the Karo Regency Regional Personnel Agency, but the employees who are appointed are not necessarily in accordance with the needs of the BPBD. This explains 
that BPBD still has shortcomings related to backgrounds that are not in accordance with the fields in the office, but the shortcomings possessed by human resources are covered by the dedication of employees as policy implementers such as self-study, associated with policy implementations of Desa Tangguh Bencana (Disaster Resilient Village) establishment. In addition, to support policy implementers to work optimally, it is supported by the provision of incentives. In carrying out the activities for the establishment of a Disaster-Resilient Village, the policy implementer, in this case, is appropriate, where those who work are in the field of prevention and preparedness for the Karo Regency BPBD, starting from program preparation, budgeting, implementation of activity authority and evaluation of the implementation of activities held by the field of prevention and preparedness. Regarding SOPs in the field of prevention and preparedness in implementing the establishment of a disaster-resilient village, there is no SOP yet. In addition, the Karo Regency BPBD does not yet have a Disaster Management SOP. In terms of coordination, the Prevention and Preparedness Sector has coordinated and communicated well because it always involves all elements needed in the formation of the Disaster Resilient Village.

\section{SUGGESTION}

The Karo Regency Regional Disaster Management Agency should make SOPs for Management of Disaster, particularly in Prevention Area and Preparedness in implementing Priority Program for the Establishment of Disaster Resilient Villages (Destana) in Karo Regency so that policy implementation runs smoothly. And the Head of BPBD conducts training for all employees (staff) and proposes to ask the Karo Regent to place employees who match their educational background and experience in the disaster field. Regarding the existing facilities in the village, needed more focus on it and provide best facilities for the fostered village so that in its implementation the Disaster Resilient Village (Destana) can run well and provide benefits for the village community.

\section{REFERENCES}

[1] Law Number 24 Year 2007 about Mitigation of Disaster.

[2] The Johns Hopkins and Red Cross Red Crescent Public, Health Guide in Emergencies, Second edition, Geneva, Switzerland, 2008.
[3] C.E. Haque (Edt.), Mitigation of Natural Hazards and Disasters: International Perspectives, Springer, Netherlands, 2005

[4] Nursa'ban, Sugiharyanto, dan Khotimah, Pengukuran kerentanan longsor lahan sebagai upaya mitigasi bencana di perbukitan menoreh. Jurnal Penelitian Saintek, 15 (2), 2010, hal. 42-52.

[5] Sugiharyanto, T. Wulandari, dan S. Wibowo, Persepsi mahasiswa pendidikan ips terhadap mitigasi bencana gempa bumi, JIPSINDO, 2 (1), 2014, hal. 164-182.

[6] P.S. Ariyati, T.F. Fathani, dan W. Wilopo, Pemetaan risiko multi bencana kota balikpapan, Jurnal Dialog Penanggulangan Bencana Vol. 9, No. 1, 2018, Hal. 52-65.

[7] H. Khan, Disaster Management Cycle a Theoretical Approach, Pakistan, Institution Information of Technology Abbottabad, 2008.

[8] G.E. Edward, Implementing Public Policy. Washington DC, Congressional Quarterly Inc., 1980.

A. Dussuet \& C. Ledoux, Implementing the french elderly care allowance for home-based care: bureaucratic work, professional cultures and gender frames, Policy and Society, Routledge, United Kingdom, Vol. 38, No. 4, 2019, pp. 589605.

[9] R. Nugroho, Public Policy. Edisi Ke-empat Revisi, PT Elex Media Komputindo, Jakarta, 2013.

[10] S. Suwitri, Konsep Dasar Kebijakan Publik, Badan Penerbit Universitas Diponegoro, Semarang, 2008.

[11] D.W. Bromley, Economic Interests and Institutions: The Conceptual Foundations of Public Policy, Basil Blackwell Ltd, Oxford, 1989.

[12] Y. Sarvina, Aspek hidrometeorologi dalam menumbuhkan budaya sadar bencana di indonesia, Jurnal Dialog Penanggulangan Bencana Vol. 9, No. 1, 2018, Hal. 9-17.

[13] M.I. Pradika, S.R. Giyarsih, dan Hartono, Peran pemuda dalam pengurangan risiko bencana dan implikasinya, Jurnal Ketahanan Nasional Vol. 24, No.2, Agustus 2018, Hal 261-286.

[14] J. Widodo, Analisis Kebijakan Publik, Konsep dan Aplikasi, Analisis Proses Kebijakan Publik, edisi ke-sepuluh, MNC Publishing, 2016.

[15] L. Agustino, Dasar-Dasar Kebijakan Publik, Edisi Revisi ke 2, Cetakan ke 8, Bandung: CV. Alfabeta, 2020.

[16] D. Indiahono, Kebijakan Publik Berbasis Dynamic Policy Analysis, Penerbit Gava Media, Yogyakarta, 2017. 